\title{
Conditions for deposition of annually laminated sediments in small meromictic lakes: a case study of Lake Suminko (northern Poland)
}

\author{
Wojciech Tylmann · Kamila Szpakowska • \\ Christian Ohlendorf • Michał Woszczyk • \\ Bernd Zolitschka
}

Received: 22 April 2011/Accepted: 21 August 2011/Published online: 9 September 2011

(C) The Author(s) 2011. This article is published with open access at Springerlink.com

\begin{abstract}
A three-year field study was conducted in Lake Suminko, Poland, to gain an understanding of the limnological variables that influence the formation and spatial extent of annually laminated sediments in the lake. The water body is divided into three depth strata, the mixolimnion, chemocline and monimolimnion, each defined by distinct values of temperature, electrical conductivity and oxygen concentration. Typical for meromictic lakes, the monimolimnion remains perennially anoxic and is rich in dissolved solids and nutrients. The annual pattern of particle flux in Lake Suminko is closely related to biochemical processes in the euphotic zone. During winter months we observed very low accumulation rates of non-carbonaceous matter, while during the rest of the year, three periods of calcite deposition were recorded (April, July-August, and OctoberNovember). The periods of high calcite deposition
\end{abstract}

W. Tylmann $(\bowtie) \cdot$ K. Szpakowska

Department of Geomorphology and Quaternary Geology, Institute of Geography, University of Gdańsk,

Gdańsk, Poland

e-mail: geowt@ug.edu.pl

C. Ohlendorf · B. Zolitschka

GEOPOLAR, Institute of Geography,

University of Bremen, Bremen, Germany

M. Woszczyk

Department of Geology and Paleogeography, Institute of Geoecology and Geoinformation, Adam Mickiewicz University in Poznań, Poznań, Poland corresponded with algal blooms and oxygen concentration maxima. Two principal factors contribute to meromixis in Lake Suminko: (1) the basin is sheltered, preventing wind mixing, and (2) biochemical processes in the lake associated with high lacustrine productivity. Meromictic conditions must control the formation and preservation of laminated sediments in the lake because preserved laminations occur only in areas where the lake floor lies below monimolimnetic waters.

Keywords Varves - Monitoring - Particle flux · Calcite deposition - Kashubian Lake District

\section{Introduction}

Lacustrine systems are influenced by a variety of environmental factors and lake responses are recorded in the physical, chemical and biological composition of their sediments. Numerous investigations demonstrate that undisturbed lacustrine sediment records are well suited for paleoenvironmental reconstruction (Renberg and Segerström 1981; O'Sullivan 1983; Zolitschka et al. 2000; Brauer 2004). The sediment archive is especially valuable if deposits are annually laminated, because varves provide an accurate, high-resolution core chronology. Varved lake sediments tend to form in regions with strongly seasonal climate, which results in intra-annual variability in primary production or allochthonous 
sediment supply (Zolitschka 2007). Another necessary requirement for the formation and preservation of annually laminated sediments is a lack of postdepositional sediment disturbance. Water currents that cause lateral sediment dislocation, as well as gas release from decomposing sediments and bioturbation, all have the potential to disrupt varve preservation (O'Sullivan 1983). Lake basins must be morphometrically suited for varve formation and preservation. The ideal lake for varve formation is sheltered from wind, flat-bottomed to prevent mass movements, and sufficiently deep to be permanently or at least seasonally stratified, so that it develops an anoxic hypolimnion (Petterson et al. 1993).

Stratification of the water column seems to be a principal precondition for varve formation. When profundal waters are isolated from surface turbulence, oxygen in the hypolimnion declines to levels that inhibit benthic organisms. Bioturbation of the sediment-water interface is thus limited, and favorable conditions are established for preservation of undisturbed sediments. Permanently stratified (meromictic) lakes are good environments for varve formation and preservation. In meromictic lakes, wind action is too weak to disrupt water-column density gradients and break down stratification (Boehrer and Schultze 2008). Such lakes remain stratified year-round and the water column displays three distinct strata, the mixolimnion, chemocline and monimolimnion. Circulation only occurs within the upper stratum, the mixolimnion. There is a steep gradient in water chemistry in the chemocline, which helps isolate deep waters from external influences. The isolated monimolimnion becomes oxygen-poor or anoxic and enriched in dissolved matter (Wetzel 2001).

The relation between anoxia and occurrence of laminated sediments is confirmed by the fact that the distribution of laminations in lakes coincides with the area covered by hypolimnetic waters (Petterson et al. 1993). Knowledge of the detailed processes that contribute to formation of annual laminations, however, is lacking, despite a number of recent studies (Larsen and MacDonald 1993; Larsen et al. 1998; Ojala et al. 2000; Zillén et al. 2003). The key to better understanding varve formation is study of modern processes in lakes. This involves monitoring of physical and chemical properties in the water column, and measurement of sediment fluxes using sediment traps (Terranes et al. 1999; Ohlendorf and Sturm 2001; Douglas et al. 2002; Bluszcz et al. 2008). Identification of the processes that give rise to laminated sediments can help prove their annual nature, and provide a strong basis for paleoenvironmental interpretation of the sediment record.

Systematic lake surveys were carried out as part of the Northern Polish Lake Research (NORPOLAR) project, to find varved sediment records in northern Poland. Several new sites with well preserved laminations were discovered (Tylmann et al. 2006; Tylmann and Zawadzka 2008). Lake Suminko is one of our key sites for reconstructing Holocene spatiotemporal climatic, hydrological, and environmental variations along a $\mathrm{W}-\mathrm{E}$ transect throughout northern Poland. This study had several objectives: (1) to document morphological, limnological and hydrochemical conditions in the lake, (2) to estimate present sediment influxes and their composition, and (3) to ascertain the limnological factors that influence the spatial extent of annually laminated (varved) sediments within the lake basin. Sound knowledge of the limnology and processes involved in varve formation will be highly informative for future detailed investigations of the paleoenvironment.

\section{Study area}

Lake Suminko $\left(17^{\circ} 47.9^{\prime} \mathrm{E}, 54^{\circ} 11.0^{\prime} \mathrm{N}, 162.8 \mathrm{~m}\right.$ a.s.1.) is located in the Kashubian Lake District in northern Poland (Fig. 1). Morphology of this region developed during the Weichselian glaciation (Pomeranian Phase, 15.2 ka BP) and represents a typical postglacial landscape in this area (Mojski 2005). Lake Suminko is situated several km south of the maximum extent of the Pomeranian terminal moraines. The entire surface of the catchment is characterized by glacio-fluvial sands and gravels of various thickness (Hydrogeological Map of Poland 2000), which are covered by podsolic soils and coniferous forests. The lake basin was most likely formed during the late glacial by melting of dead ice in a channel of the glacial outwash plane. An unpublished ${ }^{14} \mathrm{C}$ date on plant macrofossils from the base of the complete sediment profile indicates that lacustrine sedimentation began at 12.9-12.6 ka BP. Today, Lake Suminko is aligned in a SSW-NNE direction along a narrow channel with another kettle hole lake, Lake Kotynia (Fig. 1). Both are small, oval, flow-through water 


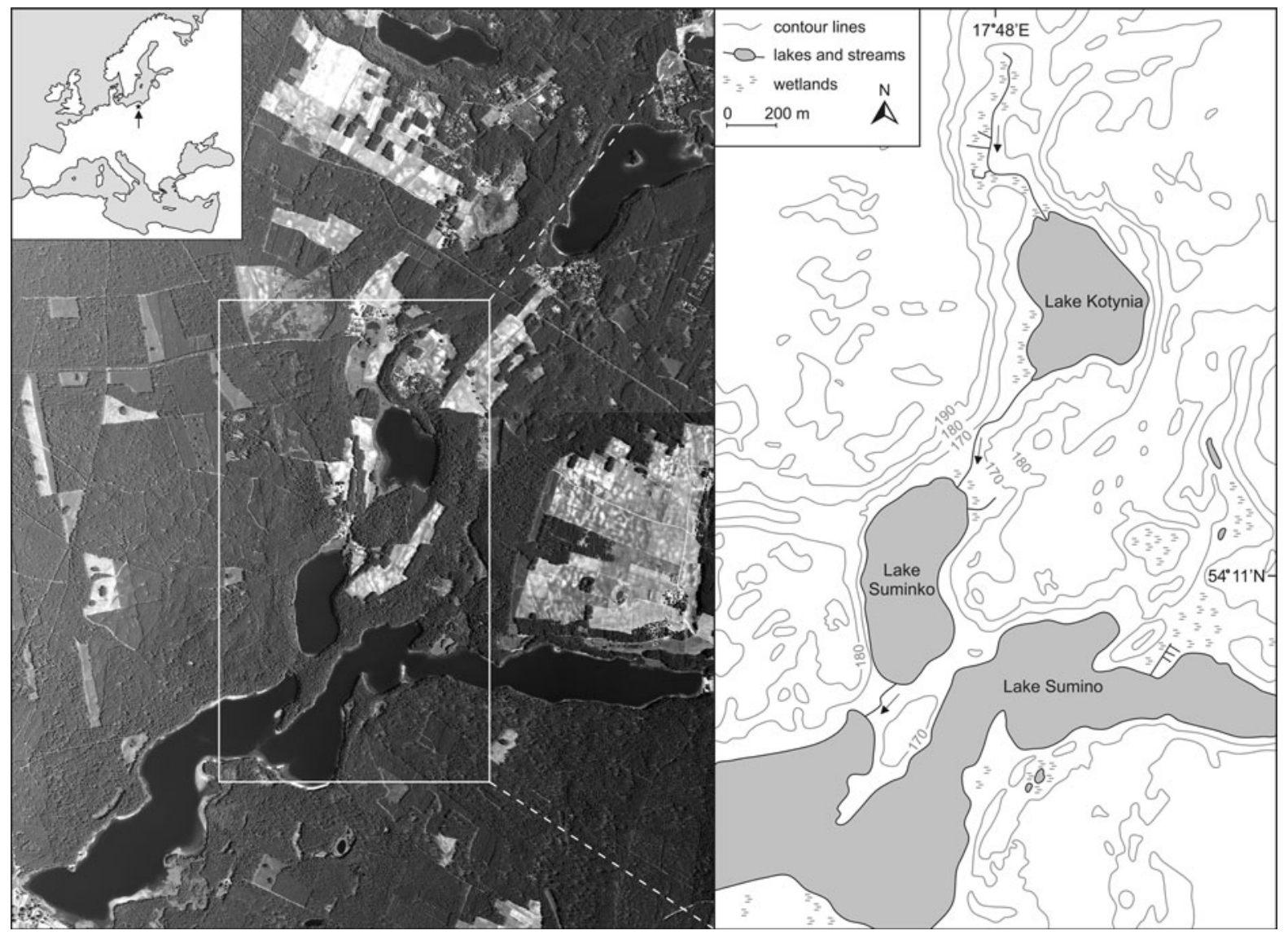

Fig. 1 Location of the study area in Poland

bodies with maximum depths of 5.6 (Kotynia) and $17.2 \mathrm{~m}$ (Suminko). Lake Suminko is sheltered by steep slopes on all sides, ranging in altitude above the lake surface from $15 \mathrm{~m}$ in the south, to $20-25 \mathrm{~m}$ along the western and eastern sides, to $30-35 \mathrm{~m}$ on the NW and NE lake shores.

Water flows southward from Lake Kotynia via a stream into the north end of Lake Suminko. An outflow stream at the south end of Lake Suminko connects to the much larger Lake Sumino (Fig. 1). Discharge measurements collected in 2004 suggest the water residence time in Lake Suminko is $<2$ years (Borowiak 2011). These data also made it clear that groundwater input is significant $(>20 \%)$ for the lake's water balance. Hydrogeological information indicates there are two aquifers in this area (Hydrogeological Map of Poland 2000). The main aquifer, with a groundwater table at $160 \mathrm{~m}$ a.s.l., is about $10-20 \mathrm{~m}$ thick and is related to outwash plain sands. The deeper, inter-morainic aquifer is isolated by glacial tills, with groundwater tables at various levels depending on the local geology. The bottom of Lake Suminko lies at $145.6 \mathrm{~m}$ a.s.1., so drainage from the main aquifer to the lake is inevitable. The lake may also receive water from the inter-morainic aquifer, but that has not been confirmed.

Meteorological data for the central part of the Kashubian Lake District were collected regularly since 1960 at the Gdansk University Limnological Station in Borucino (Miętus 2006), $15 \mathrm{~km}$ east of Lake Suminko. The study area is one of the coldest parts of Poland, with a mean annual air temperature of $6.8^{\circ} \mathrm{C}$ and distinct seasonal contrasts (Fig. 2) (Lorenc 2005). Mean annual precipitation is $670 \mathrm{~mm}$, with highest totals during summer and more precipitation in fall than spring. 

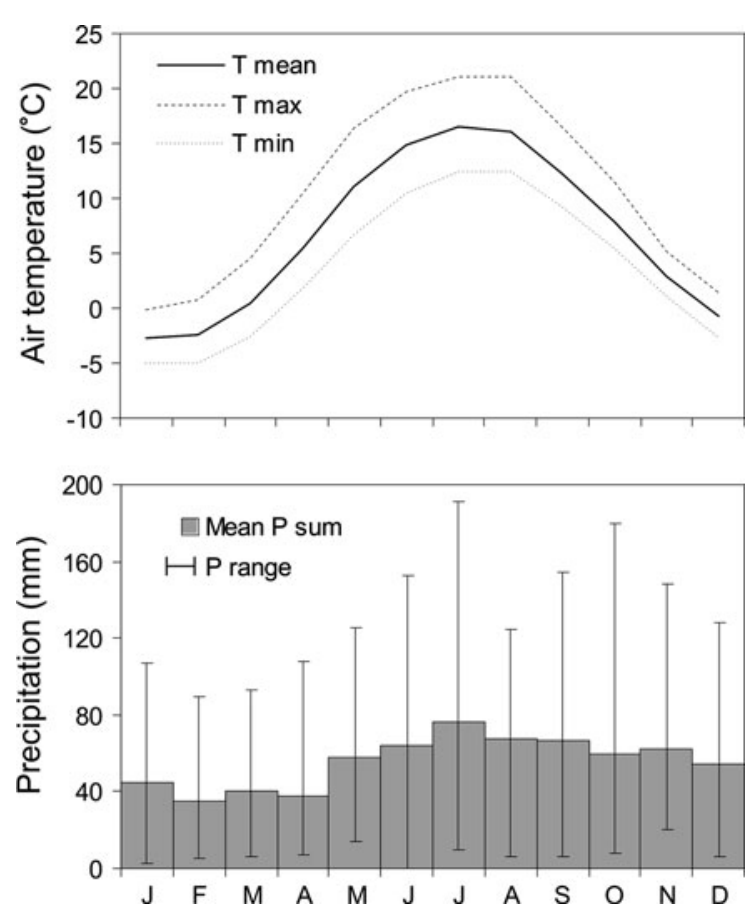

Fig. 2 Monthly mean air temperature (T) and precipitation (P) sums for the central part of the Kashubian Lake District based on instrumental data (1960-2000) obtained at the Limnological Station of the Gdańsk University at Borucino

\section{Materials and methods}

Bathymetric mapping

A bathymetric map of the lake basin was constructed using 364 water depth measurements. The shoreline was precisely determined by digitizing the topographic map $(1: 10,000)$ and corrected using an orthophotomap $(1: 5,000)$. All data points were merged and processed applying SURFER 8 software. Interpolation between measured points was done using a kriging algorithm to obtain the bathymetric contour map and a hypsographic curve. Morphometric parameters were calculated according to Håkanson and Jansson (2002).

Field measurements

In 2007, we installed a buoy at the deepest point in the lake $(17 \mathrm{~m})$ and all measurements were done at that site. During 34 monthly field campaigns between October 2007 and October 2010, physical and chemical variables in the water column (temperature, conductivity, oxygen concentration and saturation, $\mathrm{pH})$ were measured at 1-m depth intervals using a YSI 6820 meter (Yellow Spring Instruments, USA). The concentration of chlorophyll- $a(\mathrm{Chl} a)$ was measured with a Minitracka II C flourometer (Chelsea Instruments, UK). These latter measurements covered the period October 2008-June 2010. Water transparency was determined using a Secchi disc.

Hydrochemical analyses

Surface and near-bottom water samples were collected using a Van Dorn water sampler at water depths of 1 and $16 \mathrm{~m}$. Samples were placed in 1-L polyethylene bottles, transported to the laboratory and stored at $4^{\circ} \mathrm{C}$ prior to analysis. The concentration of major ions $\left(\mathrm{Ca}^{2+}, \mathrm{Mg}^{2+}, \mathrm{Na}^{+}, \mathrm{K}^{+}, \mathrm{SO}_{4}{ }^{2-}, \mathrm{Cl}^{-}\right)$ was determined by ion chromatography (ICS 1100, Dionex, USA) equipped with an Ion Pack AS22 column for anions and an Ion Pack CS16 column for cations. Total hardness and $\mathrm{HCO}_{3}{ }^{-}$were measured by standard titration methods. Nutrient $\left(\mathrm{P}_{\text {tot }}\right.$ and $\left.\mathrm{N}_{\text {tot }}\right)$ analyses were performed after sample mineralization (CrakSet 20, Merck), using the colorimetric method and a Spectroquant NOVA 400 spectrophotometer (Merck).

Water chemistry data were used to calculate the calcite saturation index (SI) according to formula 1:

$\mathrm{SI}=\log \frac{\mathrm{IAP}}{\mathrm{K}_{\mathrm{c}}}$

with IAP $=\mathrm{Ca}^{2+}$ and $\mathrm{CO}_{3}{ }^{2-}$ ion activity product and $\mathrm{K}_{\mathrm{C}}=$ equilibrium constant for the reaction:

$\mathrm{CaCO}_{3} \leftrightarrow \mathrm{Ca}_{\mathrm{aq}}^{2+}+\mathrm{CO}_{3 \mathrm{aq}}^{2-}$.

\section{Sediment flux}

We built a sediment trap using the design of Håkanson and Jansson (2002). We used four transparent PVC liners (diameter: $60 \mathrm{~mm}$, height: $650 \mathrm{~mm}$, total active area $113 \mathrm{~cm}^{2}$ ), with removable cups at the bottom. Liners were fastened together with waterproof tape, fixed on a rope and held in an upright position by a buoy installed $1 \mathrm{~m}$ below the water surface. The sediment trap was anchored on the lake bottom at a lateral distance of $3 \mathrm{~m}$ from the buoy that marked the deepest part of the lake. The active area of the trap was exposed at $1 \mathrm{~m}$ above the sediment surface. The trap 
was installed in November 2008 and recovered monthly from December 2008 to August 2010, except during winter periods with ice cover. The trap was recovered carefully to avoid re-suspension of collected particles. The solid material and supernatant water were immediately transferred from the trap into a plastic container, transported to the laboratory and stored at $4^{\circ} \mathrm{C}$ prior to analysis.

Laboratory work included smear slide preparation and microscopic inspection, dry mass estimation and total organic and inorganic carbon determinations. Smear slides were prepared from wet sediment according to the standard method (USGS manual at http:// pubs.usgs.gov/of/2001/of01-041/htmldocs/methods/ sslide.htm). After collecting a sample for smear slide preparation, particles were allowed to settle for $72 \mathrm{~h}$. The supernatant water was decanted and remaining sediment was dried slowly at $60^{\circ} \mathrm{C}$ for $48 \mathrm{~h}$. The flux of dry mass to the sediment was calculated according to formula 2 :

sediment flux $\left(\mathrm{g} \mathrm{m}^{-2} \mathrm{~d}^{-1}\right)=\frac{\text { dry net weight }(\mathrm{g})}{\text { active area }\left(\mathrm{m}^{2}\right) \times \operatorname{time}(\mathrm{d})}$

Total carbon (TC) concentration in the samples was determined using a Vario Max CNS analyzer (Elementar, Germany). The organic carbon fraction (TOC) was analyzed in carbonate-free samples using the same device. Carbonates were removed with $85 \%$ $\mathrm{H}_{3} \mathrm{PO}_{4}$. Standard reference materials (Sulfadiazine, CP1 and SQC001S) were used to assess results. Inorganic carbon (TIC) was calculated as the difference between TC and TOC, and expressed as calcite $\left(\mathrm{CaCO}_{3}\right)$ by multiplying TIC by 8.33 .

Coring

Gravity and piston cores were recovered from the deepest site in the lake $(17 \mathrm{~m})$ during the NORPOLAR field campaign in 2007. To check the lateral extent of annually laminated sediments, 24 short cores were collected during the summer of 2009 , covering the entire area of the lake bottom. Cores were taken from depths of 5, 10, 12 and $14 \mathrm{~m}$ using a gravity corer equipped with a percussion system to improve sediment penetration (Tylmann 2007). We used 100-cm-long Plexiglas core tubes with a 56-mm ID, which were cut in half lengthwise before fieldwork and re-joined using waterproof tape. Coring was done from a rubber boat stabilized by two anchors and positioned using a GARMIN eTREX GPS system. Depth at the core sites was measured with an echosounder (Humminbird 150 SX).

Cores were transported to the Gdańsk University Limnological Station in Borucino where they were opened immediately by removing the waterproof tape and split lengthwise. Exposed sediment surfaces enabled identification of sediment structures, macroscopic description and subsampling for other studies.

\section{Results}

Lake basin morphology

Morphological variables (Fig. 3) show that Lake Suminko is slightly elongated from $\mathrm{N}$ to $\mathrm{S}$, with a shoreline development index $(\mathrm{F})$ of 1.18 , a maximum depth of $17.2 \mathrm{~m}$ and a mean depth of $7.7 \mathrm{~m}$. The exposure index, which is the ratio of lake area to mean depth equals 2.1 and indicates a very low potential for mixing of the lake water column.

Slopes constitute more than $90 \%$ of the bottom area. Mean slope, measured along profile lines from the shoreline to the $15 \mathrm{~m}$ contour interval, varies significantly across the lake. Western and eastern slopes are short $(<100 \mathrm{~m})$ and steep, with mean angles of $8.5-9.5^{\circ}$. In contrast, slopes from the northern and southern shores are much longer $(>200 \mathrm{~m})$ and less inclined $\left(3.5-4.0^{\circ}\right)$. Flat areas are located in the central part, below a depth of 14-15 $\mathrm{m}$ and also in the narrow littoral zones along the northern and southern lake shore. The deepest part of lake $(>15 \mathrm{~m})$ has a lateral extension of $\sim 100$ $\times 50 \mathrm{~m}$, which constitutes $7.0 \%$ of the lake floor, with a mean slope in the range of $1.0-2.2^{\circ}$.

The relative hypsographic curve and the volume development index $\left(\mathrm{V}_{\mathrm{d}}^{-1}=0.75\right)$ are characteristic for the linear form of the lake basin (Håkanson and Jansson 2002). Other variables related to theoretical lake bottom dynamics (dynamic ratio, estimation of erosion and transportation areas) are not applicable due to the small surface area of Lake Suminko.

Physical and chemical properties of the lake water

We describe the annual pattern of major physicochemical properties in the lake water using 3 years of 

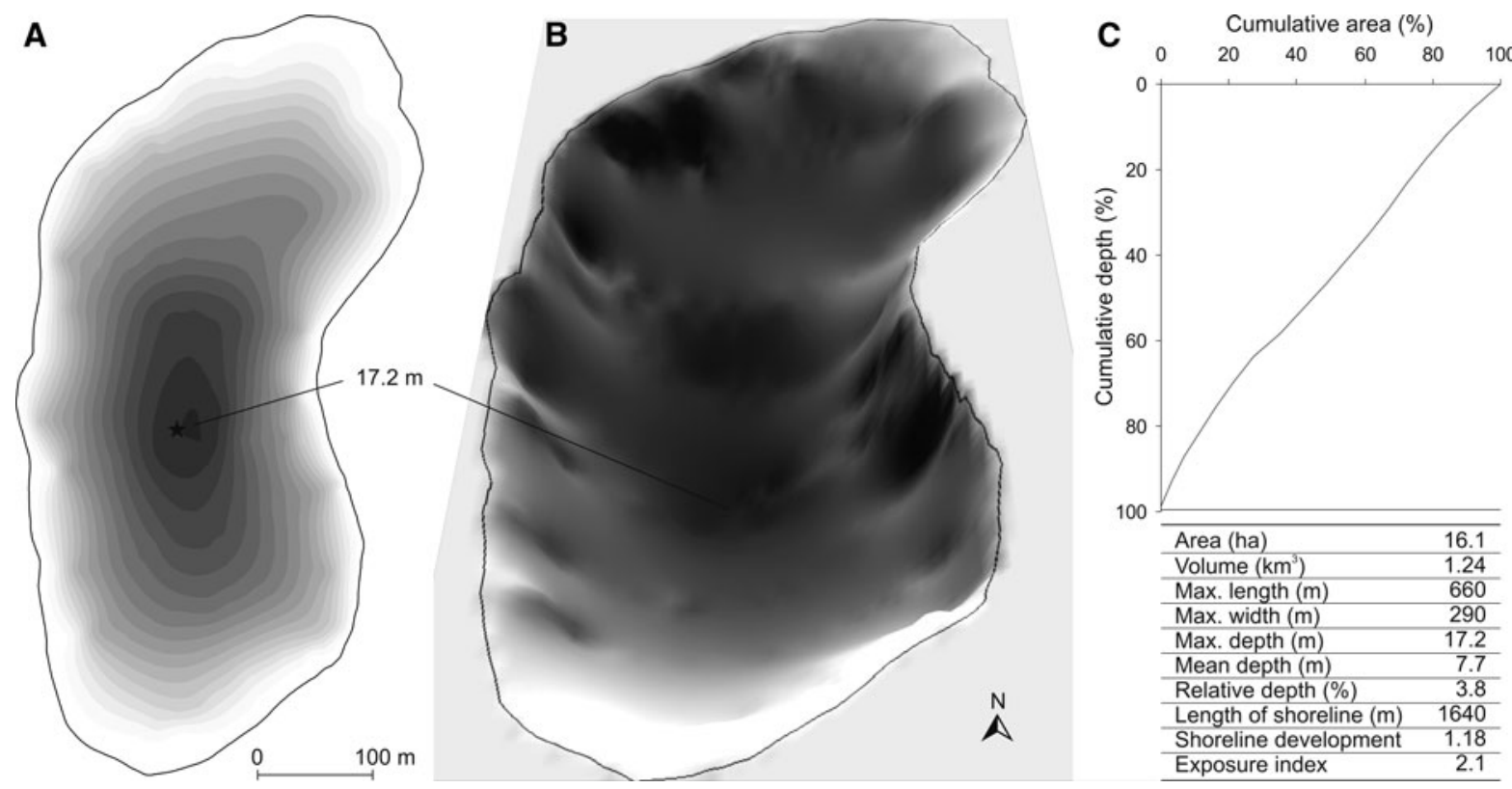

Fig. 3 Morphometry of Lake Suminko: a bathymetric map $1 \mathrm{~m}$ contours; b 3D surface plot of the lake basin; $\mathbf{c}$ hypsographic curve and morphometric parameters. The deepest point is labeled and the black asterisk marks the position of sediment trap

measurements for Lake Suminko (Fig. 4). The lake is divided into three distinct vertical strata, defined by depth profiles of temperature, conductivity and oxygen concentration. During the observation period, there were only minor differences between years.

Temperature profiles in Lake Suminko show that the water column is directly stratified during much of the year and inversely stratified during the winter months (Fig. 4a). The water surface freezes in December and the lake is covered with $15-30 \mathrm{~cm}$ of ice for about 1.5-3 months. In spring, after the lake is ice-free, heating of surface waters and weak mixing by convective turbulence begin. During summer stratification, the upper mixed zone reaches a depth of 8-9 m. At the end of September, fall overturn begins, with mixing down to $10-11 \mathrm{~m}$ water depth in late November.

The meromictic character of Lake Suminko is evident from the water column conductivity profiles (Fig. 4b). Conductivity increased from $<300$ to $>400 \mu \mathrm{S} \mathrm{cm}^{-1}$ in the depth range 9-12 $\mathrm{m}$ throughout the whole study period. The conductivity transition zone is a few meters thick and defines a chemocline. Density stratification related to temperature and/or mineralization, depending on the season, creates a well-defined monimolimnion below 12-13 m depth. The increase in conductivity with depth is generally more abrupt, and the chemocline is slightly deeper during winter stratification. During summer, the change in conductivity begins slightly higher in the water column. Conductivity in the monimolimnion remains constant throughout the year.

The deep waters of Lake Suminko remain anoxic throughout the year, typical of meromictic lakes (Fig. 4c). The oxic-anoxic boundary $\left(1 \mathrm{mg} \mathrm{L}^{-1}\right)$ ranges between 7 and $13 \mathrm{~m}$. Following establishment of ice cover, when photosynthetic oxygen production ceases or declines substantially, oxygen-consuming chemical and biological processes persist, and the anoxic boundary moves upward. There is a strong relationship between the length of the ice-cover period and the depth of the oxycline. The winter of $2007 / 2008$ was characterized by a short period of ice cover ( $<2$ months) and oxygen depletion appeared below $8 \mathrm{~m}$ water depth. During the winters of $2008 / 2009$ and $2009 / 2010$, the ice cover period was longer ( $>3$ months) and the oxygen decrease started

Fig. 4 Water properties for Lake Suminko based on in situ measurements during the years 2007-2010: a water temperature; b electric conductivity; c oxygen concentration; d chlorophyll a concentration. Thick black lines mark periods of ice cover and thin solid lines in $\mathbf{c}$ and $\mathbf{d}$ indicate euphotic zone depths 


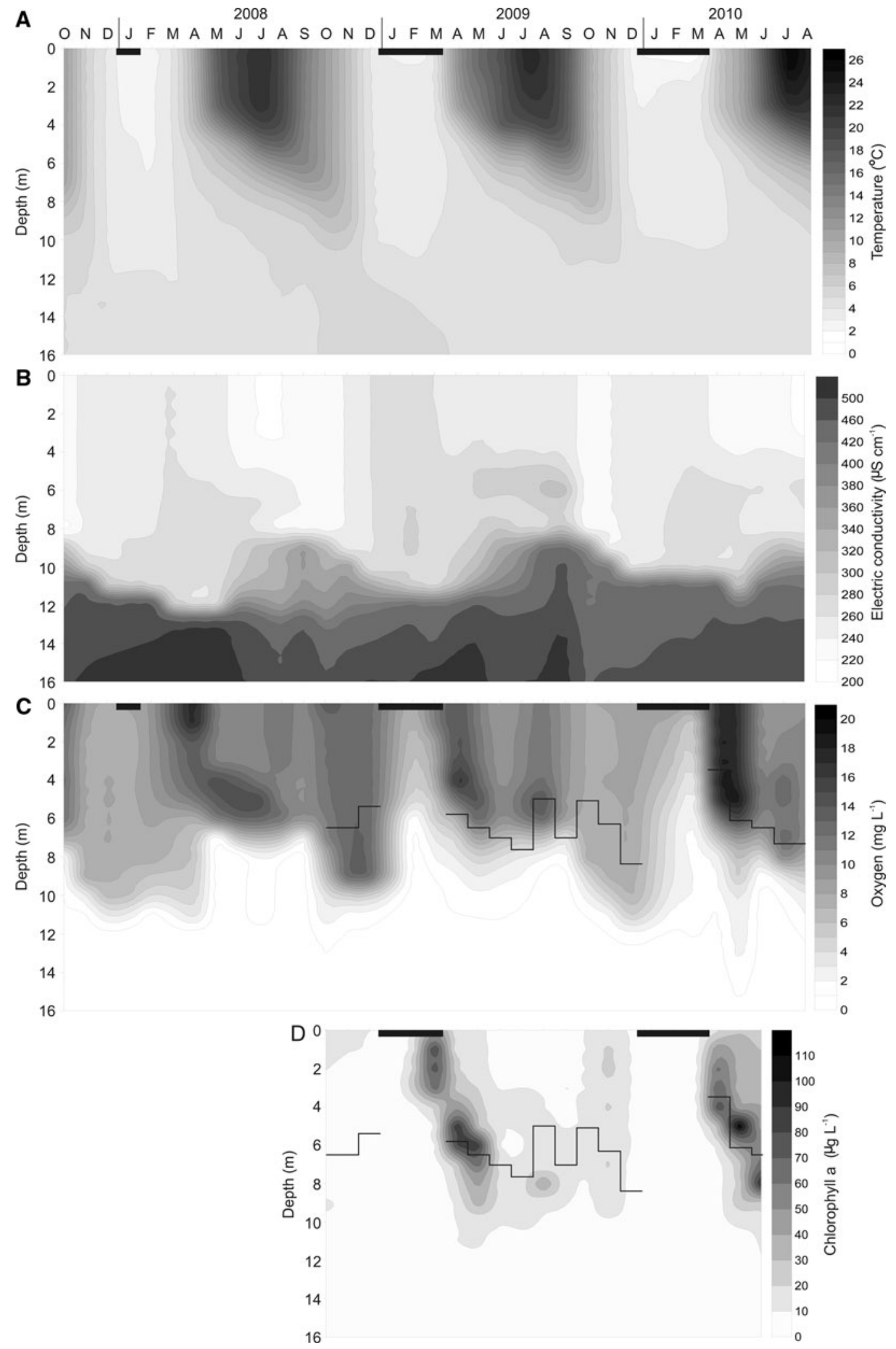


Table 1 Average chemical composition of surface and near-bottom waters of Lake Suminko

Sulfate and chloride concentrations are marked with asterisks due to smaller number of samples analyzed $(\mathrm{n}=6)$

\begin{tabular}{|c|c|c|c|c|}
\hline & \multicolumn{2}{|c|}{ Surface $(\mathrm{n}=28)$} & \multicolumn{2}{|c|}{ Bottom $(\mathrm{n}=28)$} \\
\hline & Mean & SD & Mean & SD \\
\hline $\mathrm{pH}$ & 8.1 & 0.4 & 7.2 & 0.2 \\
\hline Hardness $_{\text {tot }}\left(\mathrm{meq} \mathrm{L}^{-1}\right)$ & 2.4 & 0.2 & 4.3 & 0.2 \\
\hline Carbonate alkalinity $\left(\mathrm{meq} \mathrm{L}{ }^{-1}\right)$ & 2.0 & 0.3 & 4.2 & 0.3 \\
\hline $\mathrm{HCO}_{3}^{-}\left(\mathrm{mg} \mathrm{L}^{-1}\right)$ & 123.8 & 16.6 & 252.1 & 25.5 \\
\hline $\mathrm{Ca}^{2+}\left(\mathrm{mg} \mathrm{L}^{-1}\right)$ & 42.4 & 3.2 & 75.7 & 3.9 \\
\hline $\mathrm{Mg}^{2+}\left(\mathrm{mg} \mathrm{L}^{-1}\right)$ & 3.6 & 0.6 & 5.8 & 1.4 \\
\hline $\mathrm{Na}^{+}\left(\mathrm{mg} \mathrm{L}^{-1}\right)$ & 3.4 & 0.9 & 3.5 & 1.0 \\
\hline $\mathrm{K}^{+}\left(\mathrm{mg} \mathrm{L}^{-1}\right)$ & 1.1 & 0.2 & 1.7 & 0.2 \\
\hline $\mathrm{SO}_{4}{ }^{2-}\left(\mathrm{mg} \mathrm{L}^{-1}\right)$ & $7.7 *$ & 0.6 & $1.3^{*}$ & 0.2 \\
\hline $\mathrm{Cl}^{-}\left(\mathrm{mg} \mathrm{L}^{-1}\right)$ & $4.3 *$ & 0.4 & $4.5^{*}$ & 0.2 \\
\hline $\mathrm{P}_{\text {tot }}\left(\mathrm{mg} \mathrm{L}^{-1}\right)$ & 0.03 & 0.02 & 0.90 & 0.13 \\
\hline $\mathrm{N}_{\text {tot }}\left(\mathrm{mg} \mathrm{L}^{-1}\right)$ & 0.41 & 0.23 & 6.30 & 1.00 \\
\hline
\end{tabular}

at 1-2 $\mathrm{m}$ water depth. During the melting period the mixolimnion becomes oxygenated due to photosynthesis and turbulent mixing. Oxygen maxima related to high primary production occur in surface waters during spring (April) and at water depths of several meters during summer (June-August). In 2008 we recorded a third oxygen maximum in November.

The annual pattern of oxygen concentrations is consistent with changes in chlorophyll- $a$ (Fig. 4d), which reflect algal blooms. In 2009, the first bloom started early, at the end of March, when the lake was still covered by $15 \mathrm{~cm}$ of ice. Due to a lack of snow, light was transmitted through the ice, enabling photosynthetic activity in the top $3 \mathrm{~m}$ of water. After ice melting, an algal bloom developed and penetrated to a depth of 4-7 m, with its maximum in April $(>80 \mu \mathrm{g}$ Chl $\left.a \mathrm{~L}^{-1}\right)$. A second, weaker bloom was recorded in August at $8 \mathrm{~m}$ depth $\left(<50 \mu \mathrm{g} \mathrm{Chl} a \mathrm{~L}^{-1}\right)$, and a third appeared in November at $1-2 \mathrm{~m}$ depth $(<25 \mu \mathrm{g}$ Chl $a \mathrm{~L}^{-1}$ ). Generally, Chla concentration increased from early spring to late fall at various depths, reaching a maximum depth of $11 \mathrm{~m}$ in May. Measurements from 2010 showed the same pattern of algal bloom development. The first bloom, however, occurred later in April, when the lake was already ice-free. In March of 2010, the ice was still thick and covered by snow, so light penetration was poor. Maximum values of $>100 \mu \mathrm{g} \mathrm{Chl} a \mathrm{~L}^{-1}$ were recorded in May.

Secchi depth in Lake Suminko ranged from $3.9 \mathrm{~m}$ in December 2009 to $1.3 \mathrm{~m}$ in April 2010. We applied a simple model developed for Pomeranian lakes by Borowiak (2011) to estimate the depth of the euphotic zone (Figs. 4c, d). Temporal variations in the depth of the euphotic zone and Chl $a$ concentration correspond to locations of oxygen maxima and areas of oxygen depletion (Fig. 4c). For instance, during spring 2009, the greatest Chla concentration and oxygen maximum $\left(>16 \mathrm{mg} \mathrm{L}^{-1}\right)$ were recorded in the euphotic zone, with highest values in April. In contrast, the maximum Chla concentration recorded in August 2009 occurred below the euphotic zone. The oxygen maximum occurred within the euphotic zone, about $2 \mathrm{~m}$ above the Chla maximum, and oxygen decreased rapidly below the Chl $a$ maximum. The oxygen concentration was only $2 \mathrm{mg} \mathrm{L}^{-1}$ at $8 \mathrm{~m}$ and $<1 \mathrm{mg} \mathrm{L}^{-1}$ at $9 \mathrm{~m}$ depth.

Surprisingly, high Chla values were measured in late fall of 2009, and may have been caused by weakening of summer stratification and increased mixing of the lake water. The algal community recorded in August at $8 \mathrm{~m}$ depth might have moved upward and spread within the euphotic zone, and may have contributed to the slight increase in oxygen concentration during November.

Monthly analyses of water chemistry revealed large differences between surface and near-bottom water samples (Table 1). Total hardness, bicarbonate and calcium concentrations were twice as high in near-bottom waters as in surface samples. Even more pronounced was the difference in nutrient concentrations, which on average were 15-30 times higher near the lake bottom. These differences were accompanied 
Fig. 5 Monthly fluxes for major components (TOC, calcite) of Lake Suminko were calculated from total sediment flux and relative concentrations of TOC and TIC, respectively. Changes in calcite saturation index bottom waters are plotted along with calcite deposition (SI) for surface and near-
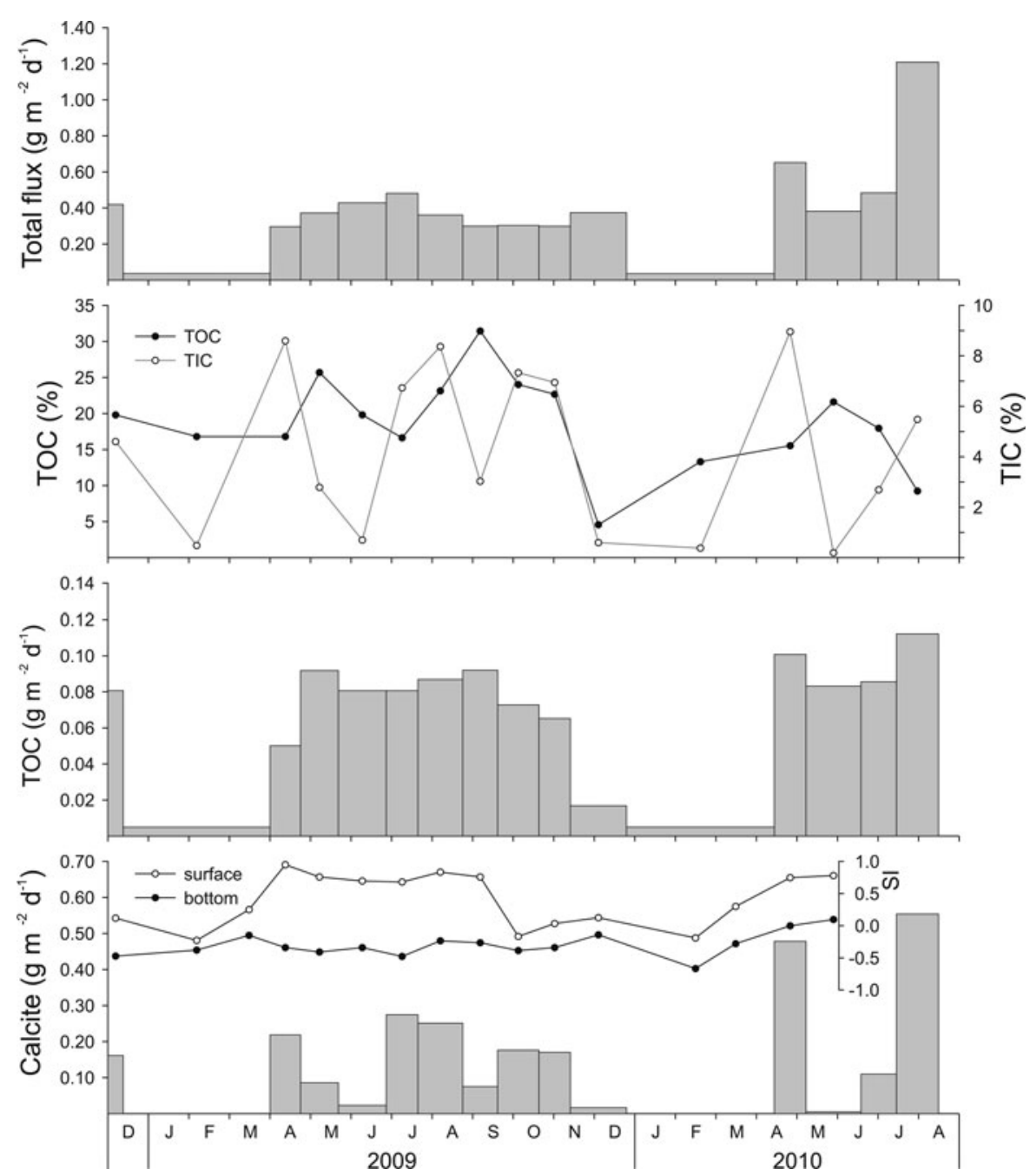

by a $\mathrm{pH}$ decrease from $>8$ to $\sim 7$, proceeding deeper into the water column. Only differences in $\mathrm{Mg}^{2+}$, $\mathrm{Na}^{+}$and $\mathrm{K}^{+}$concentrations were not statistically significant between surface and bottom waters, perhaps reflecting their conservative character in freshwaters (Wetzel 2001). Concentrations of chlorides and sulfates were very low in most samples. A strong odor of $\mathrm{H}_{2} \mathrm{~S}$ was noticed in near-bottom samples during the entire sampling period. The lack of sulfate was probably due to reduction of $\mathrm{SO}_{4}{ }^{2-}$ to $\mathrm{H}_{2} \mathrm{~S}$ under anoxic conditions (Wetzel 2001).

\section{Modern sedimentation}

Material collected at monthly intervals from the sediment trap revealed considerable changes in sediment accumulation rate during the course of the year (Fig. 5). Sediment flux ranged during the analysis period from 0.04 to $1.21 \mathrm{~g} \mathrm{~m}^{-2} \mathrm{~d}^{-1}$. Lowest values were recorded from January to March, when the lake was ice-covered. After ice out, the sedimentation rate accelerated rapidly, with a spring maximum in April or May. Sediment flux in the range $0.4-0.6 \mathrm{~g} \mathrm{~m}^{-2} \mathrm{~d}^{-1}$ was characteristic of the whole summer season, with maxima occurring during July and August. The absolute maximum was recorded in July/August 2010, when sediment flux was four times higher than average. The integrated total flux amounted to $100.1 \mathrm{~g} \mathrm{~m}^{-2} \mathrm{a}^{-1}$ in 2009 , but seems to have varied from year to year. The value calculated for January-August 2010 was $80.1 \mathrm{~g} \mathrm{~m}^{-2}$, i.e. $80 \%$ of the total 2009 sediment flux.

TOC content of sediment samples ranged from 4.5 to $31.6 \%$ and TIC values ranged from 0.2 to $8.9 \%$. 
Peaks in TIC occurred in samples from April, JulyAugust and October-November, while TOC content was highest in samples from May to September. The TOC flux was lowest during winter, increased in spring and was stable until mid-November, dropping to low values again in December. There is apparently no calcite deposition in winter, but three maxima during the growing season: spring (AprilMay), summer (July-August) and fall (OctoberNovember). The absolute deposition rates during these periods vary broadly, which is confirmed by comparison of the data from 2009 to 2010. The sample from August 2010, with highest TIC content, was analyzed by SEM to evaluate the size and shape of calcite crystals (Fig. 6). Unfortunately, small and irregular calcite crystals were mixed with diatom frustules and other organic sediment components, making it impossible to find idiomorphic calcite crystals.

Periods of calcite deposition were generally consistent with changes in the calcite saturation index (SI) of surface waters (Fig. 5). Values of SI $>0.2$ indicate favorable conditions for calcite precipitation, while values $<0.2$ indicate conditions for calcite dissolution (Baumgartner et al. 2006). The most positive values were recorded from April to September while negative values were characteristic for winter, when the lake was ice-covered. Monimolimnetic waters had negative SIs throughout the entire study period, with the exception of August 2010, when a slightly positive value was measured.

Unfortunately, it was not possible to estimate biogenic silica and minerogenic matter contents because the amount of collected sediment was small. Minerogenic matter seems to be a small fraction of the sediment, but biogenic silica is certainly an important component of the particle flux during some months. This was confirmed by qualitative analysis of smear slides, which showed diatoms were the most common biogenic element of the sediment matrix (Fig. 6). In 2009, the seasonal succession of diatoms was observed. During winter and spring, pennate diatoms (e.g. Synedra acus and Fragilaria subsalina) were abundant. Centric diatoms Stephanodiscus, Cyclotella, Aulacoseira, Puncticulata started to play a major role in June and were dominant throughout the summer. Pennate diatoms were abundant again from August to September.

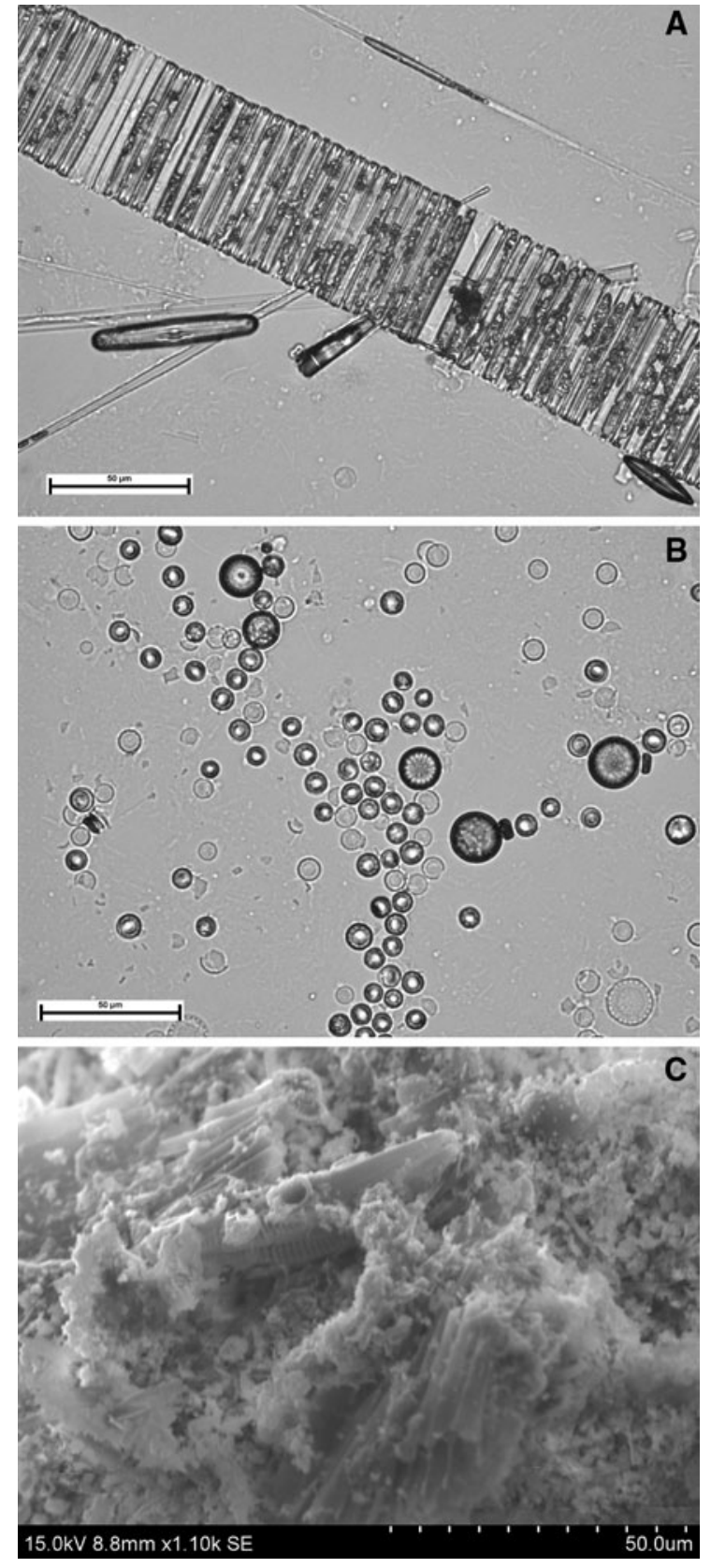

Fig. 6 Examples of smear slide and SEM images of sediment trap material. a pennate diatoms and Fragilaria (May 2009); b centric diatoms (June 2009); c SEM image showing conglomerate consisting of small and irregular calcite crystals with diatoms (August 2010)

Laminated sediments

The lateral extent of laminated sediments in Lake Suminko was determined by collecting 25 gravity 
Fig. 7 Lateral extent and general conditions for the deposition of annually laminated sediments in Lake Suminko.

1-mixolimnion;

2-chemocline;

3-monimolimnion.

Sediment core SUM-07/9-1

is taken from $17 \mathrm{~m}$ water depth and represents

sediment depth of $0-50 \mathrm{~cm}$
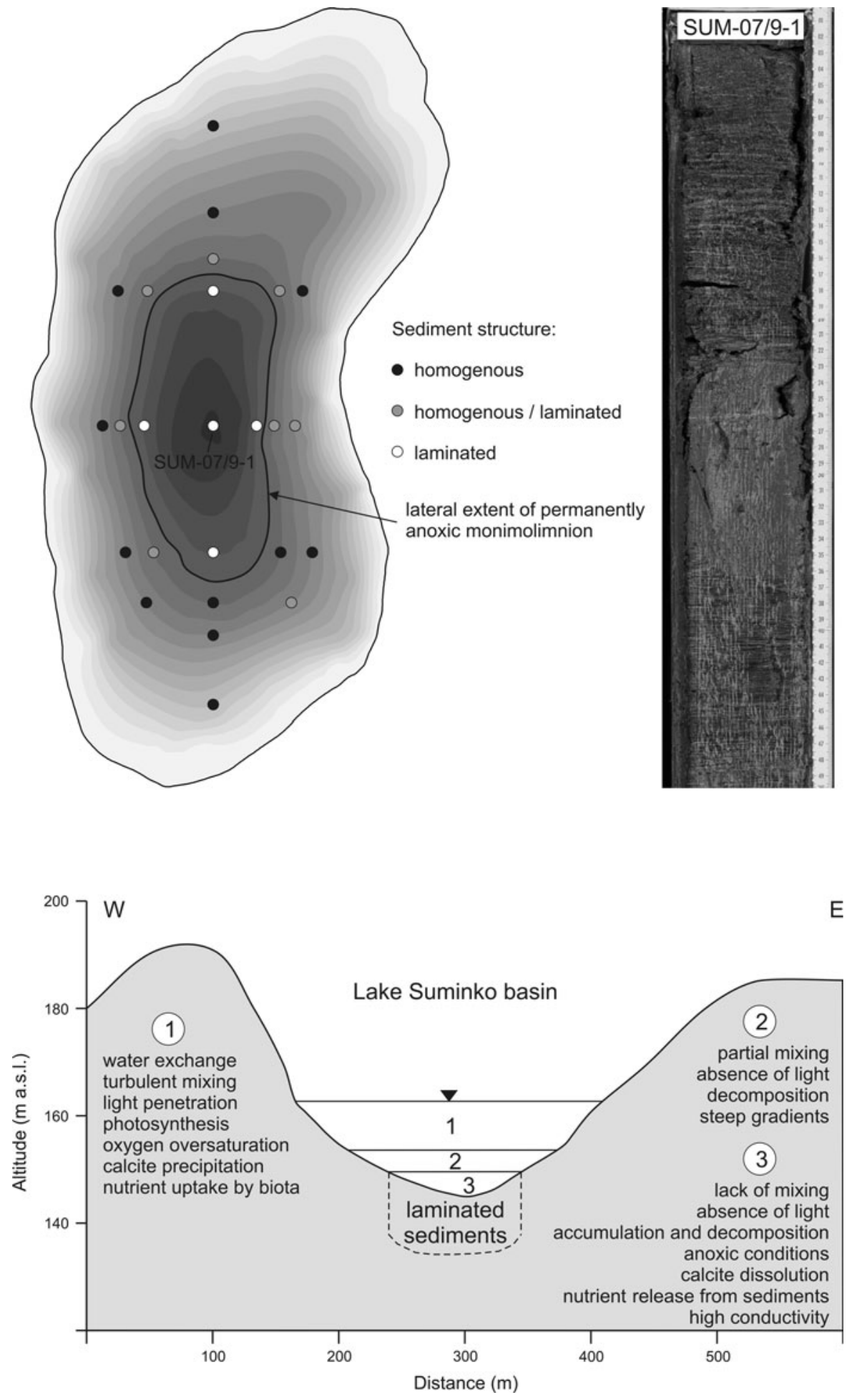

cores from locations throughout the lake (Fig. 7). photographed to evaluate preservation of sedimentary After splitting and cleaning sediment surfaces of the structures. Detailed analyses were not performed on cores for this study, as the main goal was to estimate cores, they were described macroscopically and 
the area over which deposition of annually laminated sediments occurs.

Well-preserved laminations, extending over the entire collected gravity core $(55-70 \mathrm{~cm}$ in length), were found at five locations, in water depths ranging from 14 to $17 \mathrm{~m}$. This is consistent with the areal extent of the monimolimnion (Figs. 4, 7), estimated to be that part of the water column below $13 \mathrm{~m}$ depth. Macroscopic inspection shows that varves consist of a pale and dark lamina, composed of autochthonous carbonates and detrital components, respectively. Laminae were typically $2-3.5 \mathrm{~mm}$ thick in the uppermost part of the cores and finer $(<1 \mathrm{~mm})$ in the lower part of the sequences.

Traces of varves deeper in the sediment sections were found in eight cores located at water depths between 10 and $12 \mathrm{~m}$. Because of poor preservation and the fact that varves covered $<10 \%$ of the section, these cores were classified as homogenous. Conditions at these locations are not favorable for preservation of long and undisturbed sequences of laminated sediments.

\section{Discussion}

Meromictic lakes are defined as lakes that do not mix completely. They often display a distinct difference in the chemistry of the upper and lower portions of the water column (Wetzel 2001). Various factors may be indicative of meromixis (Hakala 2004a): (1) morphometric features of the lake basin, (2) a salinity gradient, (3) an oxygen gradient, and (4) a density gradient. Depending on the local situation, one or more of the above conditions can contribute to incomplete mixing of the water column. Our data indicate that the meromictic character of Lake Suminko can be attributed to: (1) lake bathymetry and catchment morphometry, and (2) biochemical processes in the water column related to high lacustrine productivity. These factors ultimately influence the sedimentation of particles within the lake basin.

Morphological and hydrological conditions

Catchment and lake basin morphology can reduce the potential of wind action to mix the water column effectively (Håkanson and Jansson 2002). Lake Suminko is located in an elongated depression characterized by steep slopes and possesses dense forest along the shoreline. Its relatively small size and sheltered location result in a small effective wind fetch and wind protection, which prevent vertical mixing of the water column. Moreover, the relatively small surface area and considerable maximum depth ensures that the profundal parts of the lake are undisturbed by water circulation (O'Sullivan 1983). The above factors favor incomplete mixing and are the primary reasons for meromixis in Lake Suminko. A similar mechanism, called the "morphogenic effect," was described for Lake Vähä-Pitkusta (Hakala 2004b), where morphology of the small, deep basin and its sheltered location resulted in weak, wind-driven mixing and development of a density gradient that led to meromixis. The morphometric features of many meromictic lakes in Scandinavia (Kjensmo 1967; Meriläinen 1970; Hongve 1997, 2002; Hakala 2004a) and North America (Anderson et al. 1985) are very similar to those of Lake Suminko.

The hydrogeological setting of the lake and estimates of water balance suggest the lake receives groundwater input. The lake probably receives water from the shallow ("outwash plain") aquifer, but seepage into the lake from the deeper ("intermorainic") aquifer is also possible. This problem remains unresolved because of the small number of wells drilled in the area. Water temperature and chemical data from the two aquifers, however, suggest that groundwater input to the monimolimnion is unlikely. The temperature of the monimolimnion in Lake Suminko varies in the range $4-5.5^{\circ} \mathrm{C}$, while both aquifers have water temperatures in the range 6.5-7.5 ${ }^{\circ} \mathrm{C}$ (Hydrogeological Map of Poland 2000). Moreover, the "outwash plain" and "inter-morainic" aquifers have average conductivities of 230 and 170 $\mu \mathrm{S} \mathrm{cm}^{-1}$, respectively (Hydrogeological Map of Poland 2000). Therefore, groundwater input does not explain the high conductivity $\left(>400 \mu \mathrm{S} \mathrm{cm}^{-1}\right)$ in Lake Suminko's monimolimnion. We suspect that any groundwater input occurs in the mixolimnion, most likely near steep slopes, where sediment cover is not continuous.

Stratification and lake productivity

Lake Suminko displays three strata, the mixolimnion and monimolimnion, divided by a zone of sharp changes in chemical and physical water properties 
(Fig. 4). Limnological measurements indicate the mixolimnion of Lake Suminko extends over the water depth range from 0 to $9 \mathrm{~m}$, the zone of steep gradients is between 9 and $13 \mathrm{~m}$ water depth, and the monimolimnion lies below $13 \mathrm{~m}$. The thickness of the chemocline, however, varies seasonally, from 1 to $4 \mathrm{~m}$. Consequently, the depth ranges of the mixolimnion and monimolimnion also vary. Using the estimated depth boundaries above, volumes of the water strata and their respective proportional volumes are as follows: (1) the mixolimnion $=1,013,474 \mathrm{~m}^{3}$ $(81.6 \%),(2)$ the chemocline $=180,920 \mathrm{~m}^{3}(14.6 \%)$, and (3) the permanently anoxic monimolimnion = $47,373 \mathrm{~m}^{3}(3.8 \%)$.

Spring and fall overturn of the mixolimnion influences the position of the upper boundary of the chemocline. It lies about $3 \mathrm{~m}$ deeper during the period of overturn compared to the time of summer stratification (Fig. 4b). Annual variations in the position and areal extent of the chemocline caused by climatic and hydrological factors were reported earlier and seem to be common (Rogozin et al. 2010). In some meromictic lakes, intense mixolimnetic circulation can erode the upper part of the monimolimnion (Walker 1974; Hongve 1980; Boehrer and Schultze 2008). This is usually a consequence of exceptionally windy conditions that cause a deepening of thermocline and oxycline. A distinct mixing event was observed in May 2010, when the position of the oxic-anoxic interface reached $15 \mathrm{~m}$ depth, $\sim 3$ m deeper than during 2009 and 2010. Nevertheless, a rise in density with depth was a stabilizing force, and there was insufficient energy to break down the stratification.

Circulation homogenizes oxygen concentrations throughout the water column, but periods of stratification are characterized by heterogeneous measures of $\mathrm{O}_{2}$, related to algal blooms (Figs. 4c, d). Oxygen maxima recorded during periods of intense photosynthetic activity reached $>18 \mathrm{mg} \mathrm{L}^{-1}$, equivalent to $>150 \%$ saturation. Oxygen depletion is tightly coupled to the length of ice cover. The winter of $2007 / 2008$ was relatively mild and ice covered the lake for only 6 weeks. In contrast, the winters of 2008/2009 and 2009/2010 were severe, with 3 months of ice cover. Protracted isolation from atmospheric oxygen in 2009 and 2010, led the oxicanoxic interface to move up to $7 \mathrm{~m}$ water depth, a phenomenon that did not occur in 2008.
The water column below a depth of $13 \mathrm{~m}$ is characterized by homogenous temperature $\left(4.0-5.5^{\circ} \mathrm{C}\right)$, high and stable conductivity $\left(400-500 \mu \mathrm{S} \mathrm{cm}^{-1}\right)$, permanent anoxia and high nutrient concentrations $\left(\mathrm{N}_{\text {tot }}>5 \mathrm{mg} \mathrm{L}^{-1}, \mathrm{P}_{\text {tot }}>0.8 \mathrm{mg} \mathrm{L}^{-1}\right)$. These observations are consistent with the fact that meromixis causes anoxia and accumulation of nutrients in the monimolimnion (Hutchinson 1957). Higher conductivity in monimolimnetic waters of Lake Suminko is presumably a consequence of elevated $\mathrm{HCO}_{3}{ }^{-}$concentrations, indicated by the fact that total hardness is almost equal to carbonate alkalinity (Table 1). The main sources of high dissolved solids in the monimolimnion of Lake Suminko are related to microbial mineralization of organic matter and dissolution of precipitated calcite (Dean 1999). The latter is corroborated by negative SI values in near-bottom waters throughout most of the study period (Fig. 5). As a result, calcium and bicarbonate concentrations in deep waters are substantially higher than in surface waters. A similar phenomenon has been reported for numerous lakes. For example, in Lago di Lugano, $>60 \%$ of the precipitated calcite is dissolved in the water column (Ramish et al. 1999). In deep lakes, intense calcite dissolution may even induce meromixis and thus contribute to water column stability (Rodrigo et al. 2001). In addition to higher calcium content, nutrients utilized by organisms in the mixolimnion are released and trapped in the monimolimnion by processes of organic matter decay. Another feature of Lake Suminko's monimolimnion is the high concentration of hydrogen sulfide from anaerobic decomposition of organic matter.

Meromixis in Lake Suminko can be classified as endogenic (class B, type IV) according to the scheme of Walker and Likens (1975). This is equivalent to the biogenic type of Hutchinson (1957). Figure 7 presents the generalized morphological conditions and biochemical processes in the lake. The primary factor responsible for meromixis is the lake morphology, which protects the water body from wind-induced mixing. The chemical stratification originates from decomposition of organic matter in the monimolimnion and dissolution of its final products. An increase in lacustrine productivity causes a stronger chemical gradient between the mixolimnion and the monimolimnion. Stability of the stratification in Lake Suminko, however, is difficult to assess because of the lack of long-term monitoring. Unpublished profiles of temperature, conductivity and oxygen concentration from 
2004 show conditions similar to what we found (D. Borowiak, pers. commun.). Lakes, however, do not necessarily display the same circulation pattern every year (Boehrer and Schultze 2008). Meromixis may not be a permanent state, and there may be a switch to holomixis (monomixis or even dimixis), if only for short periods of time (Melack and Jellison 1998; Holzner et al. 2009). Ongoing study of varves in a long sediment core from Lake Suminko, spanning the last ca. 12.6-12.9 ka, will shed light on this issue.

\section{Sedimentary effect}

Material collected in sediment traps is regarded as an estimate of particle flux from the lake water column to bottom sediments, with respect to quantity and composition of sediment material (Catalan et al. 2002; Bradbury et al. 2004). Despite potential technical problems and possible over- or under-trapping (Bloesch and Burns 1980; Blomqvist and Håkanson 1981; Flower 1990), traps are powerful tools that provide key information about sediment formation (Douglas et al. 2002; Chu et al. 2005; Bluszcz et al. 2008).

The annual pattern of particle flux in Lake Suminko is closely related to biochemical processes in the euphotic zone. The chemical and physical composition of the sediment exhibits intra-annual changes that can be related to conditions in the lake throughout the year. We observed very low rates of sedimentation of non-carbonaceous material during winter months. It is difficult to estimate the significance of biogenic silica and minerogenic matter contribution to the sediment. Analyses were not possible due to the small amount of sediment trapped. At the time of ice out, biological activity accelerated in the lake and sediment accumulation rates increased considerably. Smear slide analysis indicates diatoms, i.e. biogenic silica, were an abundant component of the sediment matrix. High TOC values $(20-30 \%)$ in most samples emphasize the importance of organic matter. Calcite, however, plays a crucial role as a sediment component, accounting for $>70 \%$ of the sediment mass in some samples. The non-carbonate minerogenic component is thus insignificant.

Calcite is precipitated mainly during spring and summer. Precipitation during fall also occurs (Fig. 5). In 2009, three periods of calcite deposition were recorded (April, July-August, and October-November), which coincide with algal blooms and oxygen concentration maxima. Similar to many hardwater lakes, calcite precipitation is triggered by biochemical mechanisms as a consequence of supersaturation in the biogenic zone (Hodell et al. 1998). The possibility of multiple periods of calcite deposition within a year should be addressed in future geochronological studies. Recognition of annual cycles will require careful microstratigraphic investigation and cross-checking, using independent dating methods.

Meromixis in Lake Suminko is responsible for the occurrence of annually laminated sediments (Fig. 7). The spatial occurrence of laminated deposits fits exactly with what is expected, i.e. sediments with well-preserved laminations occur at sites covered by monimolimnetic waters. The presence of a monimolimnion is a consequence of both specific limnological processes and special lake morphology. The relatively flat area below $13 \mathrm{~m}$ water depth provides an ideal setting for undisturbed sedimentation. Laminated or partially laminated sediment cores were also retrieved from areas of the lake floor below the chemocline. Partial mixing events and steep slopes create a more dynamic environment in some areas, leading to poorly preserved and discontinuous laminations. Such partially laminated deposits found in cores beyond the modern monimolimnion may indicate that such anoxic deep waters covered a broader area in the past.

\section{Conclusions}

Water column stratification in Lake Suminko revealed that the lake is endogenically meromictic, as a consequence of its morphometry and high primary productivity. Stability of lake stratification throughout the year is manifested by conductivity and oxygen measures. Thermal and chemical conditions in the lake affect the intra-annual pattern of sedimentation. In general, sedimentation within the lake basin is controlled by the following factors:

- sheltered location and basin morphology that minimize wind-driven turbulent mixing;

- high productivity in the mixolimnion creates conditions favorable for precipitation of authigenic calcite;

- permanent anoxia and a low saturation index in the monimolimnion, which leads to dissolution of precipitated calcite; 
- ice cover during winter months inhibits carbonate and biogenic sedimentation.

Calcite precipitation occurred with various intensities during the warm season (April-November), and was associated with three algal blooms. Multiple periods of algal and calcite deposition have implications for identifying the annual cycle in sediments. Indeed, varve structure may be quite complex. A "black and white" couplet may not represent an annual varve in depositional environments like that of Lake Suminko. The possibility that multiple calcite layers are deposited within a single year needs to be verified by microstratigraphic investigation of thin sections from sediment cores, and cross-checked by independent dating methods. Information about the complex processes that produce laminae in modern sediments of Lake Suminko will be used to interpret long cores taken from the lake for Holocene paleoenvironmental reconstructions.

Acknowledgments Field and laboratory research for this study was supported by the Polish Ministry of Science and Education grant NN306 275635, "Record of climatic and environmental changes in annually laminated lake sediments from Northern Poland" to W. Tylmann. Excellent field assistance by Dariusz Borowiak, Kamil Nowiński, and Jacek Barańczuk (University of Gdańsk) is greatly appreciated. We also thank Artur Cysewski for laboratory analyses of water samples and Monika Lutyńska for help with identification of diatoms in smear slides. This is a contribution to the bilateral scientific program "Northern Polish Lake Research" (NORPOLAR), a Polish-German research initiative funded by the Deutsche Forschungsgemeinschaft and the Polish Ministry of Science and Education.

Open Access This article is distributed under the terms of the Creative Commons Attribution Noncommercial License which permits any noncommercial use, distribution, and reproduction in any medium, provided the original author(s) and source are credited.

\section{References}

Anderson RY, Dean WE, Bradbury JP, Love D (1985) Meromictic lakes and varved sediments in North America. US Geol Surv Bull 1607:1-19

Baumgartner LK, Reid RP, Dupraz C, Decho AW, Buckley DH, Spear JR, Przekop KM, Visscher PT (2006) Sulfate reducing bacteria in microbial mats: changing paradigms, new discoveries. Sediment Geol 185:131-145

Bloesch J, Burns NM (1980) A critical review of sedimentation trap technique. Schweiz Z Hydrobiol 42:15-55
Blomqvist S, Håkanson L (1981) A review on sediment traps in aquatic environments. Arch Hydrobiol 91:101-132

Bluszcz F, Kirilova E, Lotter AF, Ohlendorf C, Zolitschka B (2008) Global radiation and onset of stratification as forcing factors of seasonal carbonate and organic matter flux dynamics in a hypertrophic hardwater lake (Sacrower See, northeastern Germany). Aquat Geochem 14:73-98

Boehrer B, Schultze M (2008) Stratification of lakes. Rev Geophys 46:RG2005

Borowiak D (2011) Zróżnicowanie właściwości optycznych wód jeziornych Pomorza. University of Gdańsk, Gdańsk

Bradbury JP, Colman SM, Reynolds RL (2004) The history of recent limnological changes and human impact on upper Klamath Lake, Oregon. J Paleolimnol 31:151-165

Brauer A (2004) Annually laminated lake sediments and their paleoclimatic relevance. In: Fisher $\mathrm{H}$ et al (eds) Climate in historical time: towards a synthesis of holocene proxy data and climate models. Springer, Heidelberg, pp 108-128

Catalan J, Ventura M, Brancelj A, Granados I, Thies H, Nickus U, Korhola A, Lotter AF, Barbieri A, Stuchlik E, Lien L, Bitusik P, Buchaca T, Camarero L, Goudsmit GH, Kopacek J, Lemcke G, Livingstone DM, Muller B, Rautio M, Sisko M, Sorvari S, Sporka F, Strunecky O, Toro M (2002) Seasonal ecosystem variability in remote mountain lakes: implications for detecting climatic signals in sediment records. J Paleolimnol 28:25-46

Chu G, Liu J, Schettler G, Li J, Sun Q, Gu G, Lu H, Liu Q, Liu T (2005) Sediment fluxes and varve formation in Sihailongwan, a maar lake from northeastern China. J Paleolimnol 34:311-324

Dean WE (1999) The carbon cycle and biochemical dynamics in lake sediments. J Paleolimnol 21:375-393

Douglas RW, Rippey B, Gibson CE (2002) Interpreting sediment trap data in relation to the dominant sediment distribution process in a lake. Arch Hydrobiol 155:529-539

Flower RJ (1990) Seasonal changes in sedimenting material collected by high aspect ratio sediment traps operated in a holomictic eutrophic lake. Hydrobiologia 214:311-316

Hakala A (2004a) Meromixis as a part of lake evolution: observations and a revised classification of true meromictic lakes in Finland. Boreal Environ Res 9:37-53

Hakala A (2004b) The origin and evolution of Lake VähäPitkusta, SW Finland-a multi-proxy study of a meromictic lake. Hydrobiologia 527:85-97

Håkanson L, Jansson M (2002) Principles of Lake sedimentology. The Blackburn Press, Caldwell

Hodell DA, Schelske CL, Fahnenstiel GL, Robbins LL (1998) Biologically induced calcite and its isotopic composition in Lake Ontario. Limnol Oceanogr 43:187-199

Holzner CP, Aeschbach-Hertig W, Simona M, Veronesi M, Imboden DM, Kipfer R (2009) Exceptional mixing events in meromictic Lake Lugano (Switzerland/Italy), studied using environmental tracers. Limnol Oceanogr 54:1113-1124

Hongve D (1980) Chemical stratification and stability of meromictic lakes in the Upper Romerike district. Schweiz Z Hydrobiol 42:171-195

Hongve D (1997) Cycling of iron, manganese, and phosphate in a meromictic lake. Limnol Oceanogr 42:635-647

Hongve D (2002) Seasonal mixing and genesis of endogenic meromixis in small lakes in southeast Norway. Nord Hydrol 33:189-206 
Hutchinson GE (1957) A treatise on limnology. Vol. 1. Geography, Physics and Chemistry. Wiley, New York

Kjensmo J (1967) The development and some main features of "iron-meromictic" soft water lakes. Arch Hydrobiol Suppl 32:137-312

Larsen CPS, MacDonald GM (1993) Lake morphometry, sediment mixing and the selection of sites for fine resolution palaeoecological studies. Quat Sci Rev 12:781-791

Larsen CPS, Pienitz R, Smol JP, Moser KA, Cumming BF, Blais JM, MacDonald GM, Hall RI (1998) Relations between lake morphometry and the presence of laminated lake sediments: a re-examination of Larsen and MacDonald (1998). Quat Sci Rev 17:711-717

Lorenc H (ed) (2005) Atlas klimatu Polski. IMGW, Warszawa Hydrogeological Map of Poland 1:50000 (2000) Stężyca (52). Polish Geological Institute, Warszawa

Melack JM, Jellison R (1998) Limnological conditions in Mono Lake: contrasting monomixis and meromixis in the 1990s. Hydrobiologia 384:21-39

Meriläinen J (1970) On the limnology of the meromictic lake Valkiajarvi, in the finish lake district. Ann Bot Fenn 7:29-51

Miętus M (ed) (2006) Klimat rynny Jezior Raduńskich. IMGW, Warszawa

Mojski JE (2005) Ziemie polskie w czwartorzędzie. Zarys morfogenezy. PIG, Warszawa

O'Sullivan PE (1983) Annually-laminated lake sediments and the study of Quaternary environmental changes - a review. Quat Sci Rev 1:245-313

Ohlendorf C, Sturm M (2001) Precipitation and dissolution of calcite in a Swiss high alpine lake. Arct Antarct Alp Res 33:410-417

Ojala AEK, Saarinen T, Salonen VP (2000) Preconditions for the formation of annually laminated lake sediments in southern and central Finland. Boreal Environ Res 5:243-255

Petterson G, Renberg I, Geladi P, Lindberg A, Lindgren A (1993) Spatial uniformity of sediment accumulation in varved lake sediments in northern Sweden. J Paleolimnol 9:195-208

Ramish F, Dittrich M, Mattenberger C, Wehrli B, Wüest A (1999) Calcite dissolution in two deep eutrophic lakes. Geochim Cosmochim Acta 63:3349-3356
Renberg I, Segerström U (1981) Applications of varved lake sediments in paleoenvironmental studies. Wahlenbergia $7: 125-133$

Rodrigo MA, Miracle MR, Vicente E (2001) The meromictic Lake La Cruz (Central Spain). Patterns of stratification. Aquat Sci 63:406-416

Rogozin DY, Genova SN, Gulati RD, Degermendzhy AG (2010) Some generalizations based on stratification and vertical mixing in meromictic Lake Shira, Russia, in the period 2002-2009. Aquat Ecol 44:485-496

Terranes JL, McKenzie JA, Bernasconi SM, Lotter AF, Sturm M (1999) A study of oxygen isotopic fractionation during bioinduced calcite precipitation in eutrophic Baldeggersee, Switzerland. Geochim Cosmochim Acta 63:1981-1989

Tylmann W (2007) Pobór i opróbowanie powierzchniowych, silnie uwodnionych osadów jeziornych o nienaruszonej strukturze-uwagi metodyczne i stosowany sprzęt. Przegląd Geologiczny 55:151-156

Tylmann W, Zawadzka M (2008) Nowe stanowiska laminowanych osadów jeziornych na Pojezierzu Kaszubskim. Przegląd Geologiczny 56:404-408

Tylmann W, Woźniak PP, Czarnecka K, Jaźwiecka M (2006) New sites with laminated lake sediments in north-eastern Poland: preliminary results of field survey. Limnol Rev 6:283-288

Walker KF (1974) The stability of meromictic lakes in central Washington. Limnol Oceanogr 19:209-222

Walker KF, Likens GE (1975) Meromixis and a reconsidered typology of lake circulation patterns. Verh Int Ver Theor Angew Limnol 19:442-458

Wetzel RG (2001) Limnology. Lake and river ecosystems, 3rd edn. Academic Press, London

Zillén L, Snowball I, Sandgren P, Stanton T (2003) Occurrence of varved lake sediment sequences in Värmland, west central Sweden: lake characteristics, varve chronology and AMS radiocarbon dating. Boreas 32:612-626

Zolitschka B (2007) Varved lake sediments. In: Elias SA (ed) Encyclopedia of quaternary science. Elsevier, Amsterdam, pp 3105-3114

Zolitschka B, Brauer A, Negendank JFW, Stockhausen H, Lang A (2000) Annually dated late Weichselian continental paleoclimate record from the Eifel, Germany. Geology 28:783-786 